tatyanadb@yandex.ru

\title{
INTERCULTURAL ASPECTS OF MASTERING ENGLISH LANGUAGE THEORETICAL DISCIPLINE BY CHINESE STUDENTS
}

\begin{abstract}
The process of globalization experienced by the whole international community could not but influence higher professional education. Russia is becoming an effective actor of the global educational space. Russian universities attract young people not only from the former Soviet Republics but also from China. The number of students from the PRC in Saint Petersburg State University is increasing year after year. The Department of Linguistics with its Bachelor program "English Language and English Literature" is especially popular. Today effective higher education is impossible without using a competence approach. The main goal is to make the graduates competent enough to work professionally. Here English Pragmatics and namely English Speech Act Theory are in the focus of our attention. The article is an attempt to analyze six years of experience of teaching Chinese students Theoretical grammar of the English Language and English Speech Act Theory.
\end{abstract}

Key words: Chinese students, the theory of English grammar, the Speech Act Theory, visual mentality, peculiarities of perception.

\section{INTERKULTURNI ASPEKTI SAVLADAVANJA TEORIJSKE DISCIPLINE ENGLESKOG JEZIKA KOD KINESKIH STUDENATA}

APSTRAKT: Proces globalizacije koji zahvata celokupnu međunarodnu zajednicu svakako ima uticaja i na stručno i visoko obrazovanje. Rusija postaje značajan faktor u svetu obrazovanja, a ruski univerziteti privlače mlade ljude ne samo iz bivših sovjetskih republika, nego i iz Kine. Broj studenata iz Narodne Republike Kine na Državnom univerzitetu u Sankt Peterburgu je sve veći svake godine. Odsek za lingvistiku i pripadajući program osnovnih studija "Engleski jezik i engleska književnost" je naročito popularan. U današnje vreme efikasno visoko obrazovanje nije moguće bez korišćenja razvoja kompetencija. Glavni cilj ovog pristupa jeste da se studenti obuče i da im se razviju kompetencije toliko da mogu da rade u struci. Stoga su u ovom radu engleska pragmatika i engleska teorija govornih činova u fokusu naše pažnje, pa tako analiziramo šestogodišnje iskustvo u podučavanju kineskih studenata teorijskoj gramatici engleskog jezika i engleskoj teoriji govornih činova.

Ključne reči: kineski studenti, teorija engleske gramatike, teorija govornih činova, vizuelni mentalitet, detalji percepcije.

\section{INTRODUCTION}

The process of globalization could not but influence higher professional education. Nowadays Russia is becoming an actor of the global educational space, 
with Russian universities attracting young people not only from the former Soviet Republics but also from China. The number of students from the PRC in Russian universities is increasing year after year. Saint Petersburg State University is not an exception. The Department of Linguistics with its Bachelor program "English Language and English Literature" has been especially popular recently. Nowadays we cannot think about providing effective higher education without using a competence approach facilitating a certain complex of skills and practices rather than separate ones. The main goal of the Bachelor program "English Language and English Literature" is to make the graduates competent enough to work professionally using two foreign languages, which is impossible without such disciplines as English lexicology and the theoretical grammar of the English language. It is worth mentioning that Chinese students face some specific difficulties in mastering theoretical linguistics disciplines. This article is an attempt to summarize six years of experience of teaching English lexicology and theoretical grammar of the English language at the Bachelor program "English Language and English Literature" of Saint Petersburg State university, with Chinese students constituting the overwhelming majority of the class. The author analyzes the peculiarities of Chinese students' perception of these disciplines and develops some relevant recommendations.

\section{SPEECH ACT THEORY AS A PART OF THE CURRICULUM}

The Bachelor program "English Language and English Literature" is taught in two languages - Russian and English. All foreign students who come to Saint Petersburg State University are supposed to do the Russian Language Test. Those whose level of Russian is under B1 are to take a year of the Russian language course. As a result, all first-year students including those from China can speak Russian at least at the level B1. The curriculum includes four English and four Russian classes a week during all four years of the program. All theoretical disciplines are delivered in English. The second-year curriculum includes the lectures on English Lexicology, the third-year curriculum includes the Theory of English Grammar, the fourth-year curriculum incorporates Speech Act Theory. The language of the final qualification Bachelor Paper is Russian and the subject is to be one of the problems of English semantics, lexicology or pragmatics. Each student is guided and helped by a scientific supervisor.

The theoretical disciplines are aimed at providing the basis for the final linguistics research. For this article English Speech Act Theory is taken as an example of a theoretical discipline as it is delivered for the fourth-year students who are supposed to be competent enough to be able to perceive the material in English. Therefore, we can focus on the peculiarities of the perception of Chinese students. The course includes twelve lectures with the final test at the end. So a hypothesis is put forward that taking into account the specific ethno-cultural characteristics of 
students from China, as the representatives of a certain ethno-cultural entity, should improve the effectiveness of the lecture delivering process.

The English Speech Act Theory course has the following main goals. First of all, students are supposed to get acquainted with the main ideas and concepts of the subject. Some students are going to carry out their research in this field. In order to do it successfully they need a deep understanding of the subject. Secondly, to complete successfully the final research students need some practical skills. It is not enough just to be aware of the definitions of different speech acts; students are also supposed to be able to distinguish the type of any speech act in a real dialogue taken from a novel or a story. To do it they need practicing provided in the framework of the subject. Besides that, this discipline as any other theoretical and not only theoretical one, is aimed at presenting the English language as a subject to cognition. Learning new theories and ideas are sure to deepen the students' knowledge of the English language. In addition, the subject provides the students with the understanding that any language is not only a set of skills and practices which have to be mastered in order to communicate with native speakers, but it also can be a subject to some theoretical research, which they as future linguists are supposed to be able to carry out. According to the curriculum, lectures are not accompanied by the supporting seminars. Students are provided with the course description containing discipline goals, main competences to facilitate, basic ideas and concepts to learn, an example of the final test, and a list of the papers in the field to read, as well as the class schedule.

\section{CHINESE STUDENTS SPECIFIC DIFFICULTIES}

Six years of experience of teaching students from China has enabled the author to define the following specific difficulties Chinese students usually face while mastering the subject. The first one is terminology, whereby the problem lies in the fact that English speaking linguists were the first to research the field (Austin, 1962; Searle, 1969) so all terms are derived from English words with a certain semantics. Such terms as 'communicative intention' (the main goal of the speaker), 'performative verbs' (verbs which describe a certain activity) or 'assertives' (utterances with the main goal to assert something, i.e. to provide the addressee with some information) save explanations and speak for themselves. Besides this, some of the terms, for example "directives" (utterances with the main goal to make the addressee do something) and "declaratives" (utterances which, having been pronounced change the state of the things, change the situation) sound very much alike, which makes the terms difficult to remember not only for students from the PRC, but also all other non-English speaking ones.

Another serious problem is the information/practice balance. It is rather difficult for Chinese students to analyze the communication situation as they quite often do not know the plot of the novel or short story, because English and American Literature are not taught at high schools in China and not very popular 
among young Chinese readers. For all of these reasons, it takes much more time to introduce Chinese students into the communication situation and to explain the intention of the speaker to them. Being asked to define the type of a speech act, they have to solve two tasks simultaneously - to understand the situation in the wider context and to refer it to a certain speech act. They need longer portions of text to comprehend the ideas of the speaker. Recently the situation has been getting better as a great number of Chinese students have been fond of the Harry Potter books by J. K. Rowling.

For all of these reasons students from the PRC need specific information/practice balance to master the material successfully. To help students from China to comprehend the discipline of linguistics in the most effective way we considered it expedient to adjust the way of delivering the lectures. To do it we considered it effective to define the key peculiarities of Chinese students' perception of materials in class.

\section{CHINESE ETHNIC-CULTURAL ENTITY: PERCEPTION AND MENTALITY PECULIARITIES}

The peculiarities of the perception and mentality of Chinese ethnic-cultural entity representatives have become a focus of our attention recently. Peculiar characteristics of Chinese students are stipulated by their psychology. Their specific memory, perception, expressing emotions, traditional customs and interests caused by national culture, their values and ideals greatly influence the teaching-learning process. Living conditions and a specific historical development have resulted in some ethnic-psychological characteristics of the Chinese ethnic-cultural entity. Land cultivation has always dominated in the economy of China. The necessity to develop irrigation, which meant very hard laboring, led to a significant role of collective work and the community in the life of the Chinese (Balyhina, Zhao Yujiang, 2009: 18). The philosophy of Confucius established in the IV-V centuries $\mathrm{BC}$, as well as Taoism and Buddhism, formed a special Chinese mentality.

The key to understanding the way of thinking of the Chinese is their language. The Chinese see the character not as a concept, but as an idea, as an artistic image. Therefore, it is so difficult for the Chinese to understand abstract concepts requiring reliance on the possession of logic techniques. It is the language of the hieroglyphs that led to the predominance of the visual memory type (Bol'shakova, Nizkoshapkina, 2015: 39). The typical peculiarities include the following. First of all, students from China are as a rule passive during classes due to the Chinese tradition of teaching foreign languages (Medvedeva, 2002). The teacher tends to act as a lecturer and a student is just a listener. The main reason for such a tradition is the number of students in a class at school or students in a group at university. This number varies from thirty five to eighty in comparison with fifteen as a maximum for Russian schools and universities, even for schools not specializing in languages. 
Another typical feature recognized by many is Chinese thoroughness (Sobolnikov, 2001; Redding, 1990). These students are rational and reserved in their words and acts. They prefer to think all the details over thoroughly before they start acting on something. Besides this, Chinese hate being in a hurry (Balyhina, Zhao Yujiang, 2009). They are not effective when being imposed a time limit to fulfill the task. Bin (2004) underlines that while they are generally stuck to traditional methods, they always enjoy the process itself and, on completing the work, feel happy. The representatives of the Chinese ethnic-cultural entity are characterized by visual thinking, so the way of delivering the material is vital, with visual aids being the most effective (Ling, 2003). Zhao Yujiang (2007: 114) points out the following peculiar characteristics of the Chinese. integration into the group, obeying its rules; relations of mutual assistance and support among the group members. The author's experience proves and confirms the statements mentioned above. When provided in an oral form, examples are not effective at all due to the lack of visual information. For students from China it is very difficult to take notes of the lecture, especially to write down the examples dictated. So basing on the personal experience, the author has developed a set of recommendations to enhance the effectiveness of lectures.

\section{RECOMMENDATIONS}

To make the lectures and teaching more effective the following scheme of presenting material has been proposed and produced.

\subsection{Content Handouts}

Students should be provided with content handouts for every lecture. The content handouts should contain the definitions of the key concepts with a list of clear, short examples. The handouts should be distributed only after delivering a lecture. Students are first supposed to take notes themselves and only then would they be provided with content handouts to revise the material.

\subsection{Handouts Design}

Taking into consideration the visual mentality of the students, priority should be given to visual tools of presenting the information. The handout should not exceed one page with 1.5 line spacing used, Times New Romans (14 pt). There should be a blank line between paragraphs. The subject of the lecture, the terms used to define the concepts and the examples should be in bold (or bold and italic) (see a sample in Appendix 1). All these features make the handout readable for Chinese students. For six years the author has tried several layouts and the one mentioned above has turned out to be the most effective. 


\subsection{Continuous Revision}

Each next lecture should begin with at least a twenty-minute long complete revision of the previous one. The content handouts should be used as the visual support. The revision should be organized in the form of a set of questions to the students. The lecturer is supposed to help them answer in case they have difficulty, or even explain some aspects once again. To make the revision more effective it is recommended to provide students not only with the content handouts, but also with a list of examples to analyze them during the revision.

\subsection{Examples List}

The list of examples should include not only the very speech act to be analyzed but also the speech acts explaining the context of communication. It must be borne in mind that students from China often do not know English and American literature well enough to remember the plot, but they can surely understand the situation, so, for example, examples taken from Harry Potter are likely to be quite clear for the students. The list of examples should follow the same recommendations which are developed for the content handouts. They include one page only, 1.5 line spacing, Times New Romans (14 pt), with the speech act to be analyzed printed in bold, while others describe the communication situation. There should be a blank line between paragraphs.

\subsection{Team Work}

Students from China are especially good at team work, so it is a good idea to divide the students into teams containing two to three persons each. It can help to involve all the students, even if the list of examples is not very long, and let the teams help each other analyze the examples. The analysis should resemble more a discussion than an argument.

\section{TESTING THE MATERIALS IN THE CLASSROOM}

These recommendations were followed during an experiment whose main goal was to find out the effectiveness of the developed scheme of delivering lectures on English Speech Act Theory. We knew the average result of the previous years and were, therefore, able to compare them in order to establish the effectiveness of the materials.

The course normally lasts twelve classes and one of them is reserved for the test. The students are supposed to make an oral presentation in a team and it is supposed to be devoted to a certain linguist or a group of linguists who contributed to developing the Speech Act Theory. The presentation is expected to contain three parts. The first is to be devoted to the personality of the researcher. The second part serves to present the contribution of the linguist to the Speech Act Theory 
development, whereas the third one is to explain the approach of the author with some examples. Then some examples to be analyzed by the audience are given out. The assessment criteria remain the same with every generation. They include: the assessment of the oral presentation made by each student during the term. The presentation score is $30(10$ - the presented information, 10 - the post-presentation discussion, 5 - team work, 5 - presentation design).

At the end of the course the students have to do the test (see Appendix 2), which includes one theoretical problem to present (10 points) and 6 examples of real speech acts to analyze (10 points) with the score of 20 . So the total maximum score is 50 .

The results of the tests have confirmed the effectiveness of the developed scheme, because the average score of the previous year was 33.5 (the group included 11 students), while the average score for the experimental group in the year under observation was 39.9 (the group included 12 students).

\section{CONCLUSION}

We can, therefore, conclude that the newly developed approach of teaching English Speech Act Theory which takes into account the perceptual peculiarities of students belonging to the Chinese ethnic-cultural entity can be quite effective. The results were achieved by the intensification of the presenting material, which made it easier for Chinese students to comprehend the lectures on the theoretical discipline in the field of English Linguistics.

\section{REFERENCES}

Austin, J. L. (1962). How to Do Things with Words: The William James Lectures delivered at Harvard University in 1955. Oxford: Clarendon Press.

Balyhina, Z. Y. (2009). Какие они, китайцы? Этнометодические аспекты обучения китайцев русскому языку [What are they, the Chinese? Ethnomethological aspects of teaching Chinese students English]. Bbıcmee образование сегодня, 5, 16-22.

Bin, J. (2004). Этнопсихологические особенности темперамента и обшительности у китайских и российских студентов. [EthnicPsychological Peculiarities of Chinese and Russian Students Characters] Moscow: University of Moscow.

Bol'shakova N. G., Nizkoshapkina O. V. (2015). Этноориентированная методика обучения китайских учащихся самостоятельному чтению [Еthnooriented technique of teaching Chinese students independent reading]. Education Issues: languages and specialisation, 4, 36- 41.

Ling, L. G., Ho, L., Meyer, L., Varaprasad, C., \& Young, C. (2003). Teaching English to Students from China. Singapore: Singapore University Press. 
Medvedeva, S. V. (2002). Из опьта работы с китайскими учащимися на начальном этапе обучения русскому языку // Актуальные проблемы подготовки китайских учащихся в вузах $Р \Phi$ [Some experience gained in teaching Russian to Chinese students //Relevant problems of teaching students from China in Russian universities]. Voronezh: University of Voronezh.

Redding, S. G. (1990). The Spirit of Chinese Capitalism. Berlin/New York: De Gruyter.

Searle, J. R. (1969). Speech Acts: An Essay in the Philosophy of Language. Cambridge: Cambridge University Press.

Sobolnikov, V. V. (2001). Этнопсихологические особенности китайцев [EthnicPsychological peculiarities of Chinese]. Novosibirsk: University of Novosibirsk

Zhao, Y. (2007). Учет этнопсихологических особенностей китайских учащихся в национально-ориентированных тестах по русскому языку. [Ethnopsycological features of the Chinese students in national focused tests on Russian]. Education Issues: languages and specialisation, 1, 113- 116.

Tatiana Dobrova

Državni univerzitet u Sankt Peterburgu

Fakultet lingvistike

tatyanadb@yandex.ru

\section{INTERKULTURNI ASPEKTI SAVLADAVANJA TEORIJSKE DISCIPLINE ENGLESKOG JEZIKA KOD KINESKIH STUDENATA}

\section{Sažetak}

Proces globalizacije koji zahvata celokupnu međunarodnu zajednicu svakako ima uticaja i na stručno i visoko obrazovanje. Rusija postaje značajan faktor u svetu obrazovanja, a ruski univerziteti privlače mlade ljude ne samo iz bivših sovjetskih republika, nego i iz Kine. Broj studenata iz Narodne Republike Kine na Državnom univerzitetu u Sankt Peterburgu je sve veći svake godine. Odsek za lingvistiku i pripadajući program osnovnih studija "Engleski jezik i engleska književnost" je naročito popularan. U današnje vreme efikasno visoko obrazovanje nije moguće bez korišćenja razvoja kompetencija. Glavni cilj ovog pristupa jeste da se studenti obuče i da im se razviju kompetencije toliko da mogu da rade u struci. Stoga su u ovom radu engleska pragmatika i engleska teorija govornih činova $\mathrm{u}$ fokusu naše pažnje, pa tako analiziramo šestogodišnje iskustvo u podučavanju kineskih studenata teorijskoj gramatici engleskog jezika i engleskoj teoriji govornih činova. $\mathrm{Na}$ osnovu preliminarnog testiranja uspešnosti novodizajniranog materijala možemo zaključiti da ovaj novi pristup donosi uspeh, pošto način na koji je materijal napravljen odgovara perceptualnim stilovima kineskih studenata i omogućava im bolje vizuelno pamćenje.

Ključne reči: kineski studenti, teorija engleske gramatike, teorija govornih činova, vizuelni mentalitet, detalji percepcije. 
APPENDIX 1

\section{Handout №1}

The main concepts of Austin's theory of speech-acts - the concept of the act of speech, the communicative intention, the performatives, illocution, perlocution.

Pragmatics deals with the use of sentences in the real speech. Pragmatics is focused on the relations between linguistics units and those who use them, as well as the conditions of the implementation of the linguistics units, i.e. the speech components.

In terms of pragmatics the description of the sentence should reveal the links between the type of the sentence and the communicative task that is resolves with the speech actualization of the sentence of the given type. So in terms of pragmatics the sentences differ in their communicative intentions.

Communicative intention is the inherent aspiration for resolving a certain task of communication.

We should speak of the communicative-intentional content of the sentence as the phenomenon under consideration is characterized with the following

1. it is implemented only in the conditions of speech communication;

2. it is always correlated with some thing that is out of that very sentence, i.e. the response of the addressee.

Austin in his work "How to Do Things with Words" (1962) introduced such a term as the speech act.

The speech act is a sentence performed by a speaker in the situation of direct communication with the listener.

In the theory of the speech act is considered as a three-level one. In terms of language means the speech act is implemented as a locutionary act. In terms of the manifested goal it is implemented as an illocutionary act. In terms of its results it is implemented as a perlocutionary act.

The locutionary act is an act performed in saying something, as contrasted with a locutionary act, the act of saying something, and also contrasted with a perlocutionary act, an act performed by saying something. 
The main novelty of the three-level scheme of the speech act introduced by John L. Austin is the concept of illocution or illocutionary force of the utterance.

The illocutionary act is an act

1. for the performance of which I must make it clear to some other person that the act is performed;

2. and the performance of which involves the production of what Austin calls "conventional consequences" as, e.g., rights, commitments, or obligations.

Austin pointed out that an utterance can be "performative" or "constative"

An utterance is performative just in case it is issued in the course of the "doing actions". 


\section{APPENDIX 2}

\section{FINAL TEST}

1. The classification of speech acts by Searle and Vanderveken.

2. Analyze the bold utterance in the following way:

Define for each bold utterance :

i. the class of Austin's Classification

ii. the class of Searle's Classification

iii. the class and the subclass of Chakhoyan's Classification

iv. if the speech act is direct or indirect

v. if the speech act is integral or ordinary

1.

"The question is - what do we do next?" said Bobby practically.

"Oh! Lots of things", said Frankie promptly.

2.

"Good idea. You make sure she buys something special, Honey."

"Oh, I will", she swore.

3.

"I was - I am a writer."

"Oh", she said "Don't decide anything now. It's much too soon."

4.

"Would you like me to let one of our young girls with you?"

"Oh, I'll be all right alone."

Received: 1 July 2018 Accepted: 1 September 2018 